УДК 349.22

DOI https://doi.org/10.32837/apdp.v0i90.3218

Д.О. Плехов

\title{
ДО ПИТАННЯ ПРАВОВОГО РЕГУЛЮВАННЯ ДИСТАНЦІЙНОЇ РОБОТИ В УКРАЇНІ: СУЧАСНИЙ СТАН
}

Постановка проблеми. Пандемія коронавірусу (COVID-19) продовжує створювати критичну ситуацію у сфері охорони здоров'я, викликаючи безпрецедентну дестабілізацію економіки і ринку праці. Для того щоб стримати поширення вірусу, в країнах світу були прийняті численні заходи відповідно до рекомендацій Всесвітньої організації охорони здоров'я - від фізичного дистанціювання, обмеження свободи пересування і закриття підприємств і організацій, що не відносяться до життєво важливих, до ізоляції цілих міст в різних регіонах світу.

Пандемія коронавірусу (COVID-19) позначила не тільки системні проблеми трудової сфери в Україні, пов'язані з масовим вивільненням працівників на період запровадженого урядом карантину й недотриманням мінімальних соціально-трудових стандартів, а й потребу негайного реформування трудового законодавства, пристосування його до викликів сучасності. Адже ситуація, сполучена з додержанням санітарно-епідеміологічних заходів для попередження розповсюдження коронавірусу, унеможливила здійснення трудової діяльності у звичайних умовах значної кількості працівників сфери освіти й науки, сфери фінансових послуг, допоміжних до промислового виробництва структурних підрозділів і таке подібне. Переважно виконання трудової функції цими працівниками почало провадитись із застосуванням інформаційних технологій поза їхнім робочим місцем.

Запровадження карантину та надзвичайної ситуації внаслідок поширення COVID-19 привернули особливу увагу до необхідності дистанційної роботи, масштаби і темп поширення якої в розвинених країнах дуже високі. За оцінками МОП, до пандемії COVID-19 лише 8\% світової робочої сили, або приблизно 260 млн осіб, постійно працювали вдома. Для країн ЄС у 2019 р. частка дистанційних робітників у віці 15-64 років становила лише трохи більше 5\% і залишалася такою протягом останнього десятиліття. А в США за останні 10 років кількість співробітників, які регулярно працюють з дому, виросла на $115 \%$ і досягло 2,8\% всіх працевлаштованих американців (3,9 млн. чоловік). Наявні соціологічні дослідження свідчать, що під час пандемії COVID-19 понад 35\% працівників перейшли на роботу з дому. Пандемія спровокувала давно назрілий етап технологічних та соціальних експериментів, які неабияк впливають на подальшу долю офісних працівників [1].

Актуальність дослідження. Проблематика правового регулювання дистанційної роботи працівників була предметом вивчення таких учених, як Н.Б. Болотіна, В.С. Венедіктов, Л.П. Гаращенко, В.В. Жернаков, С.А. Іванов, М.І. Іншин, І.Я. Кисельов, В.П. Кохан, А.М. Курінний, В.В. Лазор, Л.І. Лазор, А.М. Лушніков, В.М. Лушнікова, Р.З. Лівшиць, М.М. Моцар, В.І. Прокопенко, В.Д. Перевалов, П.Д. Пилипенко, М.А. Шабанова, О.М. Ярошенко та ін. Проте, не при- 
меншуючи значення наукових доробків зазначених науковців щодо дослідження вказаного питання, тематика правового регулювання дистанційної роботи працівників і наразі є досить актуальною.

Мета статті - розглянути актуальні на сьогодні питання щодо правового регулювання дистанційної роботи в Україні. Оскільки враховуючи, що дистанційна робота є новим викликом часу, який був лише прискорений пандемією, а чинне законодавство не здатне швидко реагувати на нові реалії, обрана для дослідження тема є надзвичайно актуальною. В Україні вже накопичений достатній досвід віддаленої роботи та існує потреба у розробці грунтовних рекомендацій щодо створення нових та корегування існуючих норм трудового законодавства щодо дистанційної роботи як однієї із гнучких форм зайнятості.

Виклад основного матеріалу. Питання дистанційної роботи останніми роками неодноразово обговорювалися як на науковому, так і на практичному рівнях. Науковці та практики неодноразово наголошували на актуальності цієї проблеми, особливо в сучасних умовах розвитку правової держави. Проте до 2020 року на законодавчому рівні чітко не було врегульовано порядок та умови застосування такого режиму роботи. Так, Кодекс законів про працю України (далі - КЗпП України) взагалі не містив положень про дистанційну роботу. Тому, щоб якось урегулювати це питання, за аналогією закону використовували міжнародні нормативно-правові акти, а саме Конвенцію Міжнародної організації праці про надомну працю № 177 і Рекомендацію Міжнародної організації праці щодо надомної праці № 184, національні нормативно-правові акти (Постанову Державного комітету СРСР з праці та соціальних питань «Про затвердження положення про умови праці надомників № 275/17-99 від 29.09.1981). Питання дистанційної роботи не раз згадувалося у проектах Трудового кодексу, зокрема у ст. 42 проекту від 8 листопада 2019 року [2] закріплено поняття дистанційної роботи, її порядок та умови впровадження тощо.

У зв'язку з тим, що не було належного правового регулювання дистанційної роботи, контролюючі органи ставили під сумнів такі трудові відносини, а роботодавці неохоче оформлювали їх документально [3, с. 51].

В умовах епідемічної ситуації і посилення обмежувальних заходів через поширення COVID-19 у 2020 р. ця форма зайнятості набуває особливої актуальності. Уперше дистанційну роботу було врегульовано на законодавчому рівні на початку карантину в Кодексі законів про працю України. Так, Законом України № 540 від 30 березня 2020 р. (набув чинності 2 квітня 2020 р.) «Про внесення змін до деяких законодавчих актів, спрямованих на забезпечення додаткових соціальних та економічних гарантій у зв'язку з поширенням коронавірусної хвороби (COVID-2019)» [4] було внесено зміни до поняття трудового договору, закріплено поняття дистанційної (надомної) роботи та гнучкого режиму робочого часу. Виходячи із системного аналізу норм зазначеного Закону, доходимо висновку, що законодавець у цьому Законі під дистанційною (надомною) роботою розуміє переважно тимчасове явище, яке відбувається у зв'язку з поширенням саме коронавірусної хвороби та являє собою вимушену роботу вдома через неможливість дістатися до робочого місця (транспортні проблеми), закриття окремих підприємств, установ, органі- 
зацій для відвідувачів, вимушену самоізоляцію працівників через побоювання за своє здоров'я або реальне тривале погіршення здоров'я тощо в період епідемії.

Як зазначають деякі науковці, проаналізувавши вищезазначений нормативно-правовий акт, дистанційна робота була визнана законодавцем формою організації праці, а не окремим видом діяльності з власним характером праці, чим порушується принцип єдності й диференціації правового регулювання трудових відносин. Відповідно, законодавцем не були закріплені правила щодо специфіки укладення трудового договору з дистанційним працівником (окрім обов'язкової письмової форми), умов та охорони праці й тому подібне, чим, по суті, було звужено обсяг мінімальних трудових стандартів для цієї категорії працівників. Крім того, Закон № 540-IX закріпив у КЗпП антисоціальні положення щодо вилучення з поняття трудового договору вказівки про правила внутрішнього трудового розпорядку (разом із тим, дистанційний працівник ним взагалі не підпорядковується), надав антиконституційну можливість роботодавцю змінювати істотні умови праці без згоди дистанційного працівника. Це є серйозним ударом як по колективним, так і по індивідуальним правам та інтересам працівників. Відповідно, підхід, обраний законодавцем для регулювання дистанційної роботи, за своїм характером переважно цивілістичний, а в певних деталях встановлює організаційний і дисциплінарний диктат роботодавця [5].

Згодом 4 лютого 2021 p. Верховною Радою України було прийнято Закон № 1213-IX «Про внесення змін до деяких законодавчих актів України щодо удосконалення правового регулювання дистанційної, надомної роботи та роботи із застосуванням гнучкого режиму робочого часу» [6], мета якого вдосконалення правових відносин у сфері регулювання дистанційної, надомної роботи та роботи із застосуванням гнучкого режиму робочого часу. Відповідні зміни було внесено до Кодексу законів про працю України та до Закону України «Про охорону праці», зокрема Кодекс було доповнено статтями 60-1 «Надомна робота» та 60-2 «Дистанційна робота», а також внесено зміни до ст. 20 «Гнучкий режим робочого часу».

До основних положень Закону слід віднести:

- запровадження двох самостійних видів (форм) роботи - дистанційної та надомної (відповідно до закону під час дистанційної роботи людина сама обирає, де і за яким графіком працювати, а також сама відповідає за безпеку умов праці; надомна робота, навпаки, передбачає, що людина працює за графіком компанії, але поза офісом у чітко зафіксованому місці, а роботодавець забезпечує всіма необхідними для роботи технічними засобами);

- право роботодавця при укладенні трудового договору про дистанційну або надомну роботу отримувати відомості про місце проживання або інше місце за її вибором, де буде виконуватись трудова функція (з метою належного оформлення працівника на дистанційну роботу);

- забезпечення можливості ознайомлення працівника з правилами внутрішнього трудового розпорядку, колективним договором, локальними нормативними актами роботодавця, повідомленнями та іншими документами, з якими працівник має бути ознайомлений у письмовій формі, шляхом обміну електронними документами; 
- забезпечення можливості дистанційного ознайомлення працівника з вимогами щодо охорони праці шляхом використання сучасних інформаційно-комунікаційних технологій, зокрема відеозв'язку;

- забезпечення можливості працівника поєднувати дистанційну роботу з виконанням роботи в звичайному режимі на робочих місцях у приміщеннях чи на території роботодавця;

- запровадження гнучкого графіка роботи, якщо на це погоджуються працівники і підприємство (тобто людина може сама встановлювати початок та кінець свого робочого часу, «за умови дотримання відпрацювання сумарної кількості робочих годин протягом встановленого облікового періоду»);

Важливим пунктом Закону є право батьків із дітьми до 3-х років працювати дистанційно. Більше того, в разі медичних показань батьки можуть працювати віддалено, доки дитині не виповниться 6 років. Утім, лише за умови, що роботу можна виконувати віддалено і компанія має для цього ресурси і засоби.

Також Закон дозволяє перейти на дистанційну роботу (строком до 2-х місяців), якщо працівник зазнає в офісі дискримінації (за статевою чи іншими ознаками).

Автори даного нормативно-правового акта вважають, що його прийняття дозволить забезпечити чітку регламентацію дистанційної та надомної роботи, запровадження сучасних форм дистанційної роботи, використання інформаційних технологій у процесі трудових правовідносин, а також надасть роботодавцям, у разі необхідності, можливість вжиття невідкладних дієвих заходів, спрямованих на збереження життя та здоров'я працівників. Крім того, удосконалення правового регулювання дистанційної та надомної роботи призведе до позитивного соціально-економічного ефекту через створення законодавчих стимулів для переведення великої кількості працівників з роботи за договорами цивільно-правого характеру на повноцінні трудові договори із роботодавцями. Тобто прийняття законопроекту позитивне вплине на ринок праці, права та можливості роботодавців і найманих працівників, позбавить правових колізій державні контролюючі органи.

Серед позитивних аспектів Закону зазначимо відокремлення «надомної роботи» $\mathrm{i}$ «дистанційної роботи» як самостійних форм праці і надання визначення цим правовим поняттям. А також спроба врегулювати правовідносини між працівником і роботодавцем щодо запроваджених нововведень шляхом закріплення базових положень в КЗпП. Так, укладення трудового договору про дистанційну або надомну роботу є обов'язковим, окрім випадків загрози поширення епідемії, пандемії, необхідності самоізоляції працівника та/або на час загрози військового, техногенного, природного чиіншого характеру, коли умовапро надомну або дистанційну роботу можевстановлюватися у наказі (розпорядженні) власника або уповноваженого ним органу.

$€$ незрозумілим, яким чином і яким документом, у випадку відсутності трудового договору при виконанні дистанційної роботи, будуть регламентовані, зокрема, такі питання, як: порядок і строки забезпечення працівників необхідними для виконання їх обов'язків обладнанням та іншими засобами; порядок і строки подання працівниками звітів про виконану роботу; розмір, порядок і строки виплати компенсації за використання належного або орендованого працівниками обладнання та інших засобів; порядок відшкодування витрат, пов'язаних 
з виконанням дистанційної праці. Також на думку М. Луняк, неврегульованими залишаються також такі питання: захист конфіденційної інформації (комерційної таємниці); безпека працівника та ввіреного йому обладнання (шкідливе випромінення, втручання дітей, домашніх тварин, сторонніх осіб); облік робочого часу та часу відпочинку працівника (наприклад, застосування заходів дисциплінарної відповідальності за прогул); багато інших важливих аспектів [7].

Утім, не дивлячись на окремі недоліки, вважаємо, що прийняття даного Закону - це вже позитивне явище та крок у вірному напрямку.

Висновки. Підводячи підсумок викладеному, слід констатувати, що дистанційна робота працівників є надзвичайно потрібною формою трудових відносин в умовах ринкової економіки. Дистанційна робота несе собою позитивні зміни як для окремих громадян, так і для суспільства в цілому, сприяє розвитку нових форм трудових відносин, стабілізації економіки, підвищує рівень життя населення. Даний вид зайнятості потребує подальшого законодавчого врегулювання. Потрібно забезпечити належні умови захисту прав та свобод сторін віддалених правовідносин шляхом оперативного реагування законодавців на потреби сучасних ринкових відносин, що зростають, та виклики епідемічного або надзвичайного характеру.

\section{Jimepamypa}

1. Беззуб І. Дистанційна форма зайнятості: українські та зарубіжні реалії. Громадська думка про правотворення. 2020. № 16(201). C. 4-11. URL: http://nbuviap.gov.ua/images/dumka/2020/16.pdf.

2. Проект Трудового кодексу України № 2410 від 08.11.2019. URL: https://w1.c1.rada.gov.ua/pls/ zweb2/webproc4_1?pf3511=67331.

3. Вишновецька С.В., Артеменко Ю.О. Дистанційний режим роботи як одна з істотних умов праці. Право і суспільство. 2020. № 5. С. 49-54.

4. Новіков Д.О., Лук'янчиков О.М. Про внесення змін до деяких законодавчих актів України, спрямованих на забезпечення додаткових соціальних та економічних гарантій у зв'язку з поширенням коронавірусної хвороби (COVID-19) : Закон України від 30.03.2020 р. № 540-IX. URL: https://zakon.rada.gov.ua/laws/show/540-20.

5. Цивілістичний характер змін у Кодексі законів про працю України, пов'язаних із впровадженням правового регулювання дистанційної роботи. Юридичний науковий електронний журнал. 2020. № 4. URL: http://lsej.org.ua/4_2020/25.pdf.

6. Про внесення змін до деяких законодавчих актів України щодо удосконалення правового регулювання дистанційної, надомної роботи та роботи із застосуванням гнучкого режиму робочого часу : Закон України від 04.02.2021 p. № 1213-IX. URL: https://w1.c1.rada.gov.ua/pls/zweb2/ webproc4_1?pf3511=69838.

7. Луняк М. Трудове законодавство для віддалених працівників - норми, які могли б стати ефективними. URL: https://freelancehunt.com/blog/trudovie-zakonodavstvo-dlia-viddalienikh-pratsivnikivnormi-iaki-mogli-b-stati-iefiektivnimi/. 


\begin{abstract}
Анотація
Плєхов Д. О. До питання правового регулювання дистанційної роботи в Україні: сучасний стан. Стаття.

Стаття присвячена дослідженню нормативно-правового регулювання дистанційної роботи. Зазначено, що пандемія коронавірусу (COVID-19) позначила не тільки системні проблеми трудової сфери в Україні, пов'язані з масовим вивільненням працівників на період запровадженого урядом карантину й недотриманням мінімальних соціально-трудових стандартів, а й потребу негайного реформування трудового законодавства, пристосування його до викликів сучасності. Запровадження карантину та надзвичайної ситуації внаслідок поширення COVID-19 привернули особливу увагу до необхідності дистанційної роботи, масштаби і темп поширення якої в розвинених країнах дуже високі.

Проаналізовано законодавчі акти в розглядуваній царині, виокремлено як позитивні моменти, так і негативні. Зокрема, неврегульованими залишаються питання щодо захисту конфіденційної інформації (комерційної таємниці); безпеки працівника та ввіреного йому обладнання (шкідливе випромінення, втручання дітей, домашніх тварин, сторонніх осіб); обліку робочого часу та часу відпочинку працівника (наприклад, застосування заходів дисциплінарної відповідальності за прогул) та інших важливих аспектів.

Зроблено висновок, що дистанційна робота працівників є надзвичайно потрібною формою трудових відносин в умовах ринкової економіки. Дистанційна робота несе собою позитивні зміни як для окремих громадян, так і для суспільства в цілому, сприяє розвитку нових форм трудових відносин, стабілізації економіки, підвищує рівень життя населення. Водночас даний вид зайнятості потребує подальшого законодавчого врегулювання. Потрібно забезпечити належні умови захисту прав та свобод сторін віддалених правовідносин шляхом оперативного реагування законодавців на потреби сучасних ринкових відносин, що зростають, та виклики епідемічного або надзвичайного характеру.

Ключові слова: працівник, роботодавець, трудова функція, дистанційна робота, трудове законодавство, пандемія коронавірусу (COVID-19).
\end{abstract}

\title{
Summary
}

Plekhov D. O. On the issue of legal regulation of remote work in Ukraine: current status. - Article.

The article is devoted to the study of legal regulation of remote work. It is noted that the coronavirus pandemic (COVID-19) marked not only the systemic problems of the labor sphere in Ukraine related to the mass dismissal of workers during the government quarantine and non-compliance with minimum social and labor standards, but also the need to immediately reform labor legislation. to the challenges of today. The introduction of quarantine and emergencies due to the spread of COVID-19 has drawn particular attention to the need for remote work, the scale and pace of which is very high in developed countries.

Legislative acts in the considered sphere are analyzed, both positive moments, and negative are allocated. In particular, issues related to the protection of confidential information (trade secrets) remain unresolved; safety of the employee and the equipment entrusted to him (harmful radiation, intervention of children, pets, strangers); accounting for working time and rest time of the employee (for example, the application of disciplinary measures for absenteeism) and other important aspects.

It is concluded that remote work of employees is an extremely necessary form of labor relations in a market economy. Remote work brings positive changes both for individual citizens and for society as a whole, promotes the development of new forms of labor relations, stabilization of the economy, improves living standards. At the same time, this type of employment needs further legislative regulation. It is necessary to ensure proper conditions for the protection of the rights and freedoms of the parties to remote legal relations by prompt response of legislators to the needs of today's growing market relations and the challenges of epidemic or emergency nature.

Key words: employee, employer, labor function, remote work, labor legislation, coronavirus pandemic (COVID-19). 